\title{
Uji Aktivitas Ekstrak Etanol Kulit Buah Apel \\ ( Pyrus malus, L) Terhadap Penurunan Permeabilitas Vaskuler pada Mencit Putih Jantan Strain Balb/C
}

\author{
Suparmi $^{\mathrm{a}}$, Khusnul Khotimah ${ }^{\mathrm{b}}$, Amal Fadholi ${ }^{\mathrm{b}}$

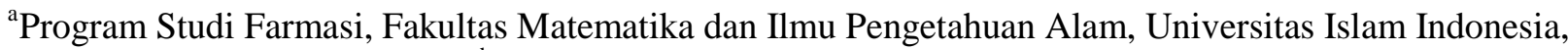 \\ ${ }^{\mathrm{b}}$ Rumah Sakit Jogja International Hospital
}

\begin{abstract}
Apple (Pyrus malus, L) is a fruit having much uses for health containing phytochemical and flavonoid substances. One of the substances contained in apple rind is quercetin. Quercetin capable to reduce vascular permeability (Mochizuki et al., 2004). The recent study has an aim to know activity of ethanol extract on apple rind to the reducing of vascular permeability thus it can used as therapies for plasma leakage in curing Dengue Blood Fever. The vascular permeability test it was done an induction method using acetate acid. Testing done on white male mice of the BALB/c strain where the mice were divided into 5 groups. The first and second groups were control groups that are a positive control were given $0.2 \mathrm{mg} / 20 \mathrm{~g}$ standard quersetin suspension and the negative one was given $0.5 \% \mathrm{Na} C \mathrm{CC}$ suspension. The third, fourth and fifth groups were treatment groups where each testing animals were given ethanol extract suspension of apple rind by dosages $0.2,0.4$, and $0.8 \mathrm{mg} / 20 \mathrm{~g}$ of Body Weight mice per oral. Taking data was done by measuring pigment intensities from abdominal cavity liquid had been washed with acetate saline. From percentages of vascular permeability reducing each group then analyzed using statistic analyses those were the one-way anova. If there was found any significant difference then it was continued a Tukey test and bivariatecorrelation. From results in the study it was known that percentages of vascular permeability reduces of ethanol extract that were made from apple rind having dosages $0.2,0.4$, and $0.8 \mathrm{mg}$ in sequences as big as $42.15 \%, 63.28 \%$ and $84.19 \%$.
\end{abstract}

Keywords: Pyrus malus, $L$, kuersetin, vascular permeability

\begin{abstract}
ABSTRAK
Apel (Pyrus malus, L) merupakan buah yang memiliki banyak kegunaan dalam kesehatan, yang mengandung zat fitokimia dan flavonoid. Salah satu zat yang terkandung dalam kulit buah apel adalah kuersetin. Kuersetin yang terkandung didalam kulit apel diketahui mampu menurunkan permeabilitas vaskuler (Mochizuki, M., et al, 2004). Berdasarkan penelitian Mochizuki maka dilakukan penelitian yang bertujuan untuk mengetahui aktivitas ekstrak etanol kulit buah apel terhadap penurunan permeabilitas vaskular sehingga dapat digunakan sebagai terapi kebocoran plasma dalam pengobatan Demam Berdarah Dengue. Uji permeabilitas vaskuler dilakukan dengan menggunakan metode induksi asam asetat. Uji aktivitas ekstrak dilakukan pada mencit jantan putih strain BALB/c yang telah dibagi menjadi 5 kelompok. Kelompok pertama dan kedua adalah kelompok kontrol, kontrol positif diberi suspensi kuersetin standar $0,2 \mathrm{mg} / 20 \mathrm{~g}$ dan kontrol negatif diberi suspensi $\mathrm{Na} \mathrm{CMC} 0,5 \%$. Kelompok ketiga, keempat, dan kelima adalah kelompok perlakuan . Pada kelompok ini , masing-masing hewan uji menerima suspensi ekstrak etanol kulit buah apel dengan dosis 0,2, 0,4 dan $0,8 \mathrm{mg} / 20 \mathrm{~g}$ BB mencit per oral. Pengambilan data dilakukan dengan mengukur intensitas warna dari cairan rongga perut hewan uji yang telah dicuci dengan salin setelah terlebih dahulu diberikan sediaan uji, diinjeksi dengan larutan trypan blue, dan asam asetat. Hasil persentase penurunan permeabilitas vaskuler tiap kelompok dianalisa dengan analisis statistik anova satu arah dan dilanjutkan uji tukey dan korelasi-bivariat. Dari hasil penelitian, diketahui persentase penurunan permeabilitas vaskuler ekstrak etanol kulit buah apel dosis 0,2, 0,4 dan $0.8 \mathrm{mg}$ berturut-turut sebesar $42,15 \%$, $63,28 \%$, dan $84,19 \%$.
\end{abstract}

Kata kunci : Pyrus malus, $L$, kuersetin, permeabilitas vaskuler 


\section{Pendahuluan}

Pengobatan DBD pada dasarnya masih bersifat suportif atau simptomatik berdasarkan kelainan utama yang terjadi yaitu berupa perembesan plasma akibat dari meningkatanya permeabilitas vaskular. Perembesan plasma yang berlangsung selama 24 sampai dengan 48 jam akan menyebabkan terjadinya syok, anoksia, asidosis, dan kematian (Nadesul, 2007). Penyebab dan mekanisme kebocoran plasma pada infeksi dengue adalah permeabilitas kapiler yang meningkat disertai peran sentral endotel yang mengalami injuri akibat sitokin, kemokin, komplemen, mediator inflamasi atau karena infeksi virus dengue sendiri secara langsung (Lei, 2001). Kerusakan dari endotelium vaskuler ini juga telah dibuktikan oleh Bhamarapravati et al, (1998) pada autopsi 100 kasus DBD.

Penelitian yang dilakukan oleh Mochizuki, M., et al tahun 2004 membuktikan bahwa kuersetin mampu menurunkan permeabilitas vaskular. Riset yang dilakukan oleh Micheal GL Hertog PhD dari Institut Kesehatan Masyarakat dan Perlindungan Lingkungan Nasional, Belanda, menunjukkan bahwa apel segar dan kulitnya mengandung kuersetin 17-55 mg dan konsentrasi rata-rata senyawa fitokimia per $100 \mathrm{~g}$ buah apel adalah kuersetin giycosia 13,2 mg.

Kuersetin yang mempunyai struktur molekul seperti dibawah ini, adalah senyawa golongan flavonoid jenis flavonol dan flavon, senyawa ini banyak terdapat pada tanaman famili myrtaceae dan solanaceae. Telah dikenal sejumlah glikosida flavonol yaitu turunan dari kuersetin, diantaranya adalah kuersetin-3-Lramnosida atau kuersitrin yang digunakan untuk pewarna tekstil, kuersetin-3-rutinosida yang biasa disebut rutin dan kuersetin-3-glukosida atau isokuersitrin yang berkhasiat diantaranya untuk mengobati kerapuhan pembuluh kapiler pada manusia (Harborne, 1987).<smiles>O=c1c(O)c(-c2ccc(O)c(O)c2)oc2cc(O)cc(O)c12</smiles>

Gambar 1. Struktur Kuersetin (Budavari, 1996) 
Penelitian ini diharapkan dapat mengetahui bahwa ekstrak etanol kulit buah apel yang mengandung zat aktif antara lain kuersetin dapat menurunkan permeabilitas vaskular sehingga dapat digunakan sebagai terapi kebocoran plasma dalam pengobatan Demam Berdarah Dengue. Sehingga hasil penelitian ini memberikan peluang untuk melihat apakah kulit buah apel bisa digunakan untuk pengobatan Demam Berdarah Dengue.

\section{Tujuan Penelitian}

Tujuan penelitian ini adalah untuk mengetahui pengaruh ekstrak etanol kulit buah apel terhadap penurunan permeabilitas vascular mencit putih jantan strain BALB/c.

\section{Metode Penelitian}

\section{Bahan dan Alat}

Bahan yang digunakan antara lain kulit buah apel (Pyrus malus, L) yang diperoleh dari Pasar Gamping, Wates, Jogjakarta. Etanol 96\% (teknis), Aquadest, Larutan $\mathrm{NaCl}$ 0,9\% (salin), Larutan trypan blue 0,5\% dalam salin, Larutan CMC Na 0,5\%, Larutan asam asetat $1 \%$ dalam salin dan kuersetin standar.

Hewan uji untuk uji permeabilitas vaskuler digunakan mencit putih strain BALB/c, jenis kelamin jantan berumur 6-8 minggu, yang diperoleh dari PAU UGM. Mencit diadaptasikan dengan lingkungan laboratorium selama 1 minggu, diberi makanan standart.

\section{Alat}

Seperangkat alat Sokletasi, vacuum rotary evaporator (Eyela), cawan porselen, penangas air (BL Barnstead Electrothermal), alat-alat gelas (Pyrex), TLC Scanner, timbangan mencit (Ohauss), Sentrifus (Beckman model J-6B Centrifuge), Spektrofotomer (Beckman Duß-65 Spectrophotometer).

\section{Cara Penelitian}

\section{Ekstraksi kulit buah apel}

Serbuk kering kulit buah apel yang diperoleh diekstraksi menggunakan etanol 69\% dengan alat Sokletasi. Filtrat yang diperoleh diuapkan dengan vacum rotary evaporator.

\section{Identifikasi senyawa aktif}

Senyawa aktif dalam ekstrak etanol kulit buah apel yang telah dijenuhkan, dibaca dengan TLC Scanner metode Densitometri pada panjang gelombang maksimum $268 \mathrm{~nm}$.

\section{Penentuan dosis standar kuersetin}

Dosis berdasarkan studi klinis Harijono Achmad (2001) di Rumah Sakit Syaiful Anwar . Sebanyak 5, $31 \mathrm{mg}$ ekstrak yang mengandung kuersetin per $50 \mathrm{kgBB}$ manusia. Berdasarkan orientasi dosis yang telah dilakukan, maka dosis kuersetin standar untuk pengujian adalah sebesar 0,2 mg/20 g BB mencit. Volume yang digunakan $=0,5 \mathrm{ml}(1 / 2$ vol. maksimal $)$. 
Larutan stock ekstrak dibuat sebanyak= (dosis/0,5ml) x jumlah hewan uji / $4 \mathrm{mg} / 10 \mathrm{ml}$ .Sebanyak 0, 004 g ekstrak etanol kulit buah apel ditimbang seksama, kemudian disuspensikan homogen dalam larutan $\mathrm{Na}$ CMC 0,5\% ad $10 \mathrm{ml}$.Dengan perhitungan yang sama, maka untuk dosis 0,4 dan $0,8 \mathrm{mg}$ adalah 0,008 dan 0,016 g ekstrak ditimbang seksama, kemudian disuspensikan homogen dalam larutan $\mathrm{Na}$ CMC 0,5\% ad $10 \mathrm{ml}$.

\section{Perlakuan pada hewan uji}

Penelitian ini menggunakan rancangan acak, lengkap dan searah. Hewan uji yang digunakan yaitu mencit putih jantan strain BALB/c berumur 6-8 minggu. Dua puluh lima ekor mencit dibagi secara acak menjadi 5 kelompok (kontrol dan perlakuan). Sebelum percobaan dilakukan, mencit dipuasakan selama 2 jam, air minum tetap diberikan. Tiap kelompok terdiri dari 5 ekor mencit dengan pengelompokkan sebagai berikut:

$\begin{aligned} \text { Kelompok I : } & \text { Kelompok kontrol negatif } \\ & \text { diberi larutan } \mathrm{Na} \text { CMC } \\ & 0,5 \% \text { per oral. }\end{aligned}$

Kelompok II : Kelompok kontrol positif diberi suspensi kuersetin standar dosis $0,2 \mathrm{mg} / 20 \mathrm{~g} \mathrm{BB}$ mencit.

Kelompok III : Kelompok perlakuan I diberi suspensi ekstrak etanol kulit buah apel dengan dosis $0,2 \mathrm{mg} / 20 \mathrm{~g}$ BB mencit.

Kelompok IV : Kelompok perlakuan II diberi suspensi ekstrak etanol kulit buah apel dengan dosis $0,4 \mathrm{mg} / 20 \mathrm{~g}$ BB mencit.

Kelompok V : Kelompok perlakuan III diberi suspensi ekstrak etanol kulit buah apel dengan dosis $\quad 0,8 \mathrm{mg} / 20 \mathrm{~g} \quad \mathrm{BB}$ mencit.

\section{Uji Permeabilitas Vaskuler yang Diinduksi} dengan Asam Asetat (Ozaky, et al, 1989)

\section{a. Prinsip pengujian}

Mengukur intensitas warna dari cairan rongga perut yang telah dicuci dengan saline, setelah diberi sediaan uji, diinjeksi dengan larutan Trypan Blue, dan Asam Asetat.

\section{b. Kriteria hasil}

$\%$ penurunan permeabilitas $=[(\mathrm{a}-\mathrm{b}) / \mathrm{a}] \mathrm{x}$ $100 \%$

$$
\begin{aligned}
\mathrm{a}= & \text { rata-rata kadar Trypan Blue }(\mu \mathrm{g} / \mathrm{ml}) \\
& \text { kelompok kontrol negatif } \\
\mathrm{b}= & \text { rata-rata kadar Trypan Blue }(\mu \mathrm{g} / \mathrm{ml}) \\
& \text { kelompok uji }
\end{aligned}
$$

Semakin jernih warna dari cairan rongga perut semakin baik efek permeabilitas vaskulernya (Olaleye, et al, 2004) 


\section{c. Cara kerja}

1. Masing-masing kelompok diberi perlakuan sesuai prosedur.

2. Setelah 40 menit hewan uji diinjeksi intravena melalui vena ekor dengan 0,5\% larutan Trypan Blue dalam saline

3. Setelah 30 menit, hewan uji diinjeksi intraperitoneal dengan 1\% larutan asam asetat dalam saline

4. Setelah 20 menit mencit dibunuh dengan dislokasi leher, kemudian dinding abdominal perut dipotong

5. Rongga perut dicuci dengan $5 \mathrm{ml}$ saline, cucian tersebut ditampung dalam tabung konikel dan disentrifugasi, kemudian diambil $1 \mathrm{ml}$ supernatan

6. Absorbansi dan supernatan diukur pada $\chi 583 \mathrm{~nm}$

\section{Hasil dan Pembahasan}

Ekstrak Etanol dengan metode Sokletasi kulit buah Apel dari bobot basah seberat 535,62 g. Menjadi Bobot kering serbuk sebanyak 100 g, Ekstraksi dengan etanol diuapkan menggunakan vacum rotary evaporator dihasilkan $29,530 \mathrm{~g}$ ekstrak kental.

Pemisahan senyawa kuersetin secara kualitatif dilakukan dengan menggunakan TLC (Thin Layer Chromatography). Fase gerak yang digunakan adalah etil asetat - asam formiat asam asetat - air dengan perbandingan 100:11:11:27 dan fase diam yang digunakan adalah selulosa. Sebagai pembanding, digunakan kuersetin standar dan pereaksi aluminium klorida. Hasil analisis secara kualitatif dapat dilihat pada gambar 2 .
UV $254 \mathrm{~nm}$

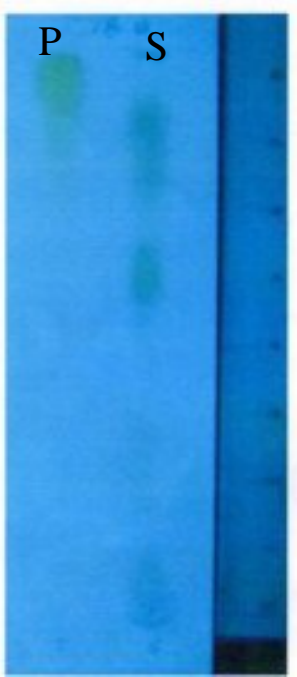

UV $365 \mathrm{~nm}$

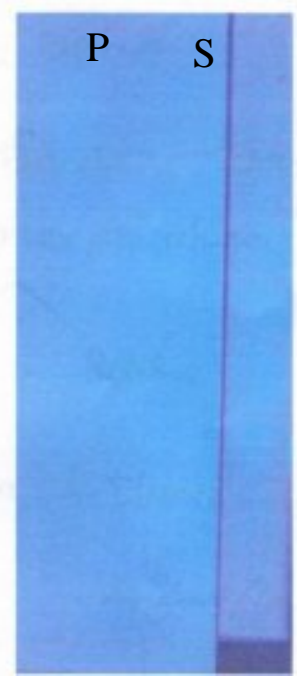

Visibel

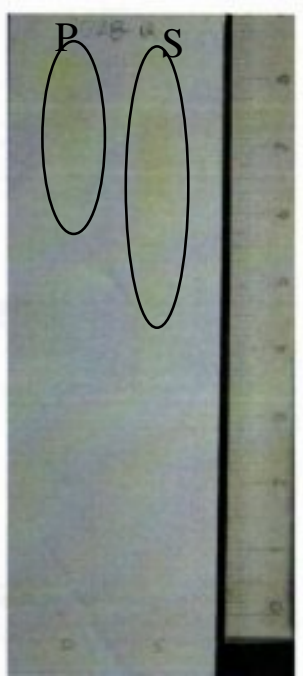

Gambar 2. Kromatogram ekstrak etanol kulit buah apel dengan pembanding kuersetin

Keterangan :

P: Pembanding kuersetin murni S: Ekstrak kulit buah apel 
Pengamatan kromatogram dibawah sinar UV 254 dan $365 \mathrm{~nm}$ terlihat bercak yang tidak begitu jelas. Namun dari hasil pengamatan dengan visibel dihasilkan bercak berwarna kuning dan hal ini bisa dipakai sebagai petunjuk positif adanya kuersetin. Harga Rf sampel sebesar 0,83. Sedangkan harga $\mathrm{Rf}$ standar kuersetin sebesar 0,8. Harga $\mathrm{Rf}$ yang saling mendekati menunjukkan bahwa di dalam ekstrak kulit buah apel terdapat kandungan senyawa kuersetin.

Uji kuantitatif kuersetin dilakukan dengan metode KLT-Densitometri. Fase diam yang digunakan adalah silika $60 \quad \mathrm{GF}_{254}$, sedangkan fase geraknya adalah kloroform: metanol:asam formiat dengan perbandingan 90:10:3. Deteksi bercak dilakukan dengan melakukan scanning pada permukaan lempeng dengan densitometer, suatu instrument yang dapat mengukur intensitas radiasi yang direfleksikan dari permukaan lempeng ketika disinari dengan lampu UV.
Persamaan kurva baku $\mathrm{Y}=17742856 \mathrm{X}$ - 11200,942 diperoleh dari regresi linear antara konsentrasi kuersetin standar dengan luas area yang terbentuk. Luas area sampel sebesar 54121,69 menunjukkan bahwa jumlah kuersetin dalam sampel adalah sebesar 0,368162 dan jumlah sampel yang ditotolkan ialah $500 \mu$ g. Kemudian kadar kuersetin diperoleh dengan cara menghitung jumlah kuersetin dalam sampel terhadap jumlah kuersetin yang ditotolkan dikalikan $100 \%$. Sehingga dapat diperoleh kadar kuersetin sebesar $0,0736 \%=736 \mathrm{ppm}$.

\section{Uji Aktivitas Ekstrak}

\section{Hasil uji}

Kriteria hasil pengujian adalah intensitas warna cairan rongga perut yang terukur makin jernih, maka makin baik efek permeabilitasnya. Dari pengujian diperoleh hasil seperti terlihat pada tabel 1 .

Tabel 1. Data absorbansi dan Persentase penurunan permeabilitas vaskuler kelompok kontrol negatif dan positif

\begin{tabular}{cccc}
\hline \multicolumn{2}{c}{ Kelompok } & absorbansi & Persentase penurunan permeabilitas vaskuler \\
\hline \multirow{4}{*}{ kontrol negatif } & Mencit 1 & 0,400 & 0 \\
& Mencit 2 & 0,480 & 0 \\
& Mencit 3 & 0,493 & 0 \\
& Mencit 4 & 0,501 & 0 \\
& Mencit 5 & 0,578 & 0 \\
& X \pm SD & $0,49 \pm 0,06$ & $0 \pm 0$ \\
& Mencit 1 & 0,227 & 53,93 \\
kontrol positif & Mencit 2 & 0,249 & 49,42 \\
& Mencit 3 & 0,280 & 43,08 \\
& Mencit 4 & 0,286 & 41,85 \\
& X \pm SD & $0,26 \pm 0,03$ & $47,07 \pm 5,65$ \\
\hline
\end{tabular}


Pada tabel 1 terlihat adanya perbedaan jumlah perlakuan pada hewan uji. Pada penelitian ini jumlah hewan uji pada satu kelompok perlakuan terdiri dari 5 mencit. Tetapi karena tidak semua hewan uji menghasilkan respon yang baik sehingga data yang diperoleh menjadi bias. Hal ini mungkin disebabkan hewan uji yang digunakan yaitu mencit mengalami stres. Stres pada mencit mungkin disebabkan belum cocoknya dengan lingkungan yang baru sehingga dibutuhkan waktu adaptasi yang lebih lama, banyaknya mencit dalam suatu kandang yang kecil sehingga mereka saling berebut untuk mendapatkan tempat yang layak. Dan mungkin karena kesalahan personal yaitu pada saat pemberian volume pemejanan, tidak sesuai dengan volume pemejanan yang sebenarnya. Hal ini terjadi karena untuk menentukan volume pemejanan yang benarbenar tepat sangat sulit dilakukan.

Pada tabel 1 juga terlihat adanya perbedaan absorbansi maupun persentase penurunan permeabilitas vaskuler pada kedua kelompok kontrol yaitu kontrol positif dan negatif. Nilai absorbansi cairan rongga perut kelompok kontrol positif yang terukur lebih kecil jika dibandingkan dengan kelompok kontrol negatif Secara visualpun bisa terlihat, cairan rongga perut kelompok kontrol negatif lebih gelap jika dibandingkan dengan kelompok kontrol positif. Semakin jernih cairan rongga perut yang terukur, semakin baik efek penurunan permeabilitas vaskulernya. Kelompok kontrol positif menunjukkan respon penurunan permeabilitas penurunan yang lebih baik dengan harga rata-rata sebesar 47, $07 \%$ sedangkan untuk kelompok kontrol negatif tidak memberikan respon dalam menurunkan permeabilitas vaskuler yang ditunjukkan dengan nilai persentase penurunan permeabilitas vaskuler sebesar 0\% Dari hasil uji statistika terlihat bahwa antara kelompok kontrol negatif dan positif terdapat perbedaan yang signifikan dalam menurunkan permeabilitas vaskuler.

Untuk mengetahui pengaruh pemberian ekstrak kulit buah apel maka persentase penurunan permeabilitas vaskuler pada masingmasing kelompok dianalisis menggunakan anova satu arah dengan taraf kepercayaan $95 \%$. Untuk melihat apakah data telah terdistribusi normal atau tidak sebelumnya dilakukan analisis terlebih dahulu dengan One Sample Kolmogorov Smirnov. Data telah terdistribusi normal, hal ini ditunjukkan dari hasil output dengan probabilitas $0,822(\mathrm{p}>0,05)$ dan data homogen yang ditunjukkan dari hasil output dengan probabilitas 0,439 $(\mathrm{p}>0,05)$ sehingga dapat dilanjutkan dengan analisis anova. Tujuan dari analisis ini adalah untuk membandingkan keefektifan terapi dalam menurunkan permeabilitas vaskuler pada masing-masing kelompok. Dari tiap perlakuan mempunyai populasi yang benar-benar berbeda secara nyata. Untuk mengetahui kelompok mana saja yang 
berbeda secara signifikan selanjutnya dilakukan $<0,05$.

analisis Tukey oleh karena probabilitasnya

Tabel 2. Data absorbansi dan persentase penurunan permeabilitas vaskuler

\begin{tabular}{|c|c|c|c|}
\hline \multicolumn{2}{|l|}{ Kelompok } & \multirow{2}{*}{$\frac{\text { absorbansi }}{0,305}$} & \multirow{2}{*}{$\begin{array}{l}\begin{array}{l}\text { Persentase penurunan } \\
\text { permeabilitas vaskule }\end{array} \\
37,96\end{array}$} \\
\hline & Mencit 1 & & \\
\hline Ekstrak etanol kulit buah apel dosis & Mencit 2 & 0,314 & 36,12 \\
\hline \multirow[t]{3}{*}{$0,2 \mathrm{mg} / 20 \mathrm{~g}$ BB mencit } & Mencit 3 & 0,286 & 41,85 \\
\hline & $\mathrm{X} \pm \mathrm{SD}$ & $0,30 \pm 0,01$ & $38,64 \pm 2,93$ \\
\hline & Mencit 1 & 0,181 & 63,35 \\
\hline Ekstrak etanol kulit buah apel dosis & Mencit 2 & 0,192 & 61,09 \\
\hline \multirow[t]{4}{*}{$0,4 \mathrm{mg} / 20 \mathrm{~g}$ BB mencit } & Mencit 3 & 0,117 & 76,45 \\
\hline & Mencit 4 & 0,225 & 54,34 \\
\hline & $\mathrm{X} \pm \mathrm{SD}$ & $0,18 \pm 0,05$ & $63,81 \pm 9,26$ \\
\hline & Mencit 1 & 0,091 & 81,77 \\
\hline Ekstrak etanol kulit buah apel dosis & Mencit 2 & 0,064 & 87,30 \\
\hline \multirow[t]{5}{*}{$0,8 \mathrm{mg} / 20 \mathrm{~g}$ BB mencit } & Mencit 3 & 0,071 & 85,87 \\
\hline & Mencit 4 & 0,085 & 83,00 \\
\hline & $\mathrm{X} \pm \mathrm{SD}$ & $0,08 \pm 0,01$ & $84,49 \pm 2,54$ \\
\hline & Mencit 1 & 0,400 & 0 \\
\hline & Mencit 2 & 0,480 & 0 \\
\hline \multirow[t]{6}{*}{ Kontrol negatif } & Mencit 3 & 0,493 & 0 \\
\hline & Mencit 4 & 0,501 & 0 \\
\hline & Mencit 5 & 0,578 & 0 \\
\hline & $\mathrm{X} \pm \mathrm{SD}$ & $0,49 \pm 0,06$ & $0 \pm 0$ \\
\hline & Mencit 1 & 0,227 & 53,93 \\
\hline & Mencit 2 & 0,249 & 49,42 \\
\hline \multirow[t]{3}{*}{ Kontrol positif } & Mencit 3 & 0,280 & 43,08 \\
\hline & Mencit 4 & 0,286 & 41,85 \\
\hline & $\mathrm{X} \pm \mathrm{SD}$ & $0,26 \pm 0,03$ & $47,07 \pm 5,65$ \\
\hline
\end{tabular}

Tabel 3. Ringkasan hasil uji Tukey setiap perlakuan

\begin{tabular}{|c|c|}
\hline Kelompok & Signifikansi \\
\hline Kontrol negatif vs kontrol positif & $0,000^{*}$ \\
\hline Kontrol negatif vs dosis $0,2 \mathrm{mg} / 20 \mathrm{~g} \mathrm{BB}$ & $0,000 *$ \\
\hline Kontrol negatif vs dosis $0,4 \mathrm{mg} / 20 \mathrm{~g} \mathrm{BB}$ & $0,000 *$ \\
\hline Kontrol negatif vs dosis $0,8 \mathrm{mg} / 20 \mathrm{~g} \mathrm{BB}$ & $0,000^{*}$ \\
\hline Kontrol positif vs dosis $0,2 \mathrm{mg} / 20 \mathrm{~g} \mathrm{BB}$ & 0,089 \\
\hline Kontrol positif vs dosis $0,4 \mathrm{mg} / 20 \mathrm{~g} \mathrm{BB}$ & 0,083 \\
\hline Kontrol positif vs dosis $0,8 \mathrm{mg} / 20 \mathrm{~g} \mathrm{BB}$ & $0,000 *$ \\
\hline Dosis $0,2 \mathrm{mg} / 20 \mathrm{~g}$ BB vs dosis $0,4 \mathrm{mg} / 20 \mathrm{~g}$ BB & $0,010 *$ \\
\hline Dosis $0,2 \mathrm{mg} / 20 \mathrm{~g}$ BB vs dosis $0,8 \mathrm{mg} / 20 \mathrm{~g}$ BB & $0,000^{*}$ \\
\hline Dosis $0,4 \mathrm{mg} / 20 \mathrm{~g}$ BB vs dosis $0,8 \mathrm{mg} / 20 \mathrm{~g}$ BB & $0,024 *$ \\
\hline
\end{tabular}

Keterangan: $*=$ berbeda signifikan

Semua dosis yang diberikan mempunyai Pada tabel terlihat adanya perbedaan yang efek terhadap penurunan permeabilitas vaskuler. signifikan antara kelompok kontrol negatif 
dengan kontrol positif maupun dari ketiga kelompok dosis. Dengan rata-rata persentase penurunan permeabilitas vaskuler kontrol positif sebesar 47,07\%, dosis 0,2mg/20g BB sebesar $38,64 \%$, dosis $0,4 \mathrm{mg} / 20 \mathrm{~g}$ BB sebesar $63,81 \%$ dan dosis 0,8mg/20g BB sebesar 84,49\%.

Pada dosis 0,2mg/20g BB dan dosis $0,4 \mathrm{mg} / 20 \mathrm{~g}$ BB mempunyai efek yang sebanding dengan kontrol positif. Hal ini dapat dilihat dari hasil uji tukey, yang mana antara dosis $0,2 \mathrm{mg} / 20 \mathrm{~g}$ BB dan dosis $0,4 \mathrm{mg} / 20 \mathrm{~g}$ BB yang dibandingkan dengan kontrol positif tidak menunjukkan perbedaan yang signifikan. Sedangkan untuk dosis 0,8mg/20g BB mempunyai efek yang lebih baik/besar dibandingkan dengan kelompok kontrol positif yang dapat dilihat dari hasil uji tukey antara dosis $0,8 \mathrm{mg} / 20 \mathrm{~g}$ BB menunjukkan perbedaan yang signifikan. Untuk masing-masing tingkatan dosis menunjukkan perbedaaan yang signifikan, yang berarti bahwa pada ketiga dosis tersebut mempunyai efek yang berbeda, yaitu semakin besar dosis semakin besar pula efek menurunkan permeabilitas vaskulernya.

Persentase penurunan permeabilitas vaskuler oleh ekstrak etanol kulit buah apel pada dosis $0,8 \mathrm{mg} / 20 \mathrm{~g}$ BB sebesar $84,49 \%$ sedangkan pada penelitian Kusumawati et al, 2004 dilaporkan ekstrak etanol daun jambu biji dosis $0,742 \mathrm{mg} / 20 \mathrm{~g}$ BB dapat menurunkan permeabilitas vaskuler hanya sebesar $56,601 \%$. Hal ini berarti bahwa ekstrak etanol kulit buah apel lebih baik efeknya terhadap penurunan permeabilitas vaskuler walaupun dosis yang diberikan hampir sama.

Gambar 3. Cairan rongga perut masing-masing perlakuan

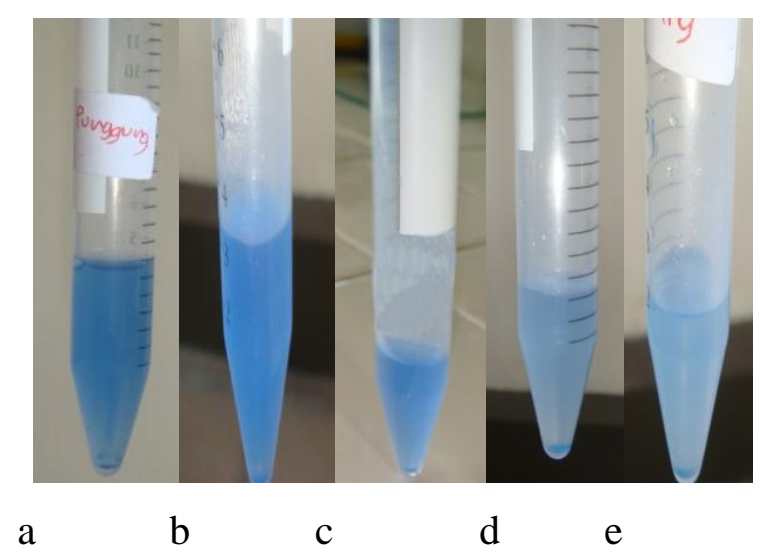

Keterangan:
a : kontrol negatif
b : kontrol positif
c : ekstrak etanol kulit buah apel dosis $0,2 \mathrm{mg} / 20 \mathrm{~g} \mathrm{BB}$
d : ekstrak etanol kulit buah apel dosis $0,4 \mathrm{mg} / 20 \mathrm{~g}$ BB
e : ekstrak etanol kulit buah apel dosis $0,8 \mathrm{mg} / 20 \mathrm{~g} \mathrm{BB}$ 
Aktivitas penurunan permeabilitas vaskuler dari ekstrak etanol dari daun jambu biji dan kulit buah apel tersebut diperkirakan tidak hanya disebabkan oleh salah satu senyawa saja yaitu kuersetin, tetapi merupakan sinergi dari beberapa kandungan senyawa yang terkandung di dalamnya.

Pada gambar 3 terlihat bahwa cairan rongga perut yang mendapatkan ekstrak etanol kulit buah apel paling besar ( gambar e : dosis $0,8 \mathrm{mg} / 20 \mathrm{~g}$ BB ) memberikan warna yang lebih jernih dibandingkan yang lain. Hal ini menunjukkan semakin jernih warna cairan rongga perut, semakin besar persentase penurunan permeabilitas vaskuler.

Diagram balok pada gambar 4 memperlihatkan bahwa kelompok yang mempunyai aktivitas penurun permeabilitas vaskuler paling tinggi adalah ekstrak etanol kulit buah apel 0,8 mg/20g BB sebesar 84,49\%, diikuti ekstrak dosis $0,4 \mathrm{mg} / 20 \mathrm{~g}$ BB sebesar 63,81\%, kontrol positif (kuersetin standar) sebesar $47,07 \%$, dan ekstrak dosis $0,2 \mathrm{mg} / 20 \mathrm{~g}$ BB sebesar 38,64\%.

Gambar 4. Diagram persentase penurunan permeabilitas vaskuler

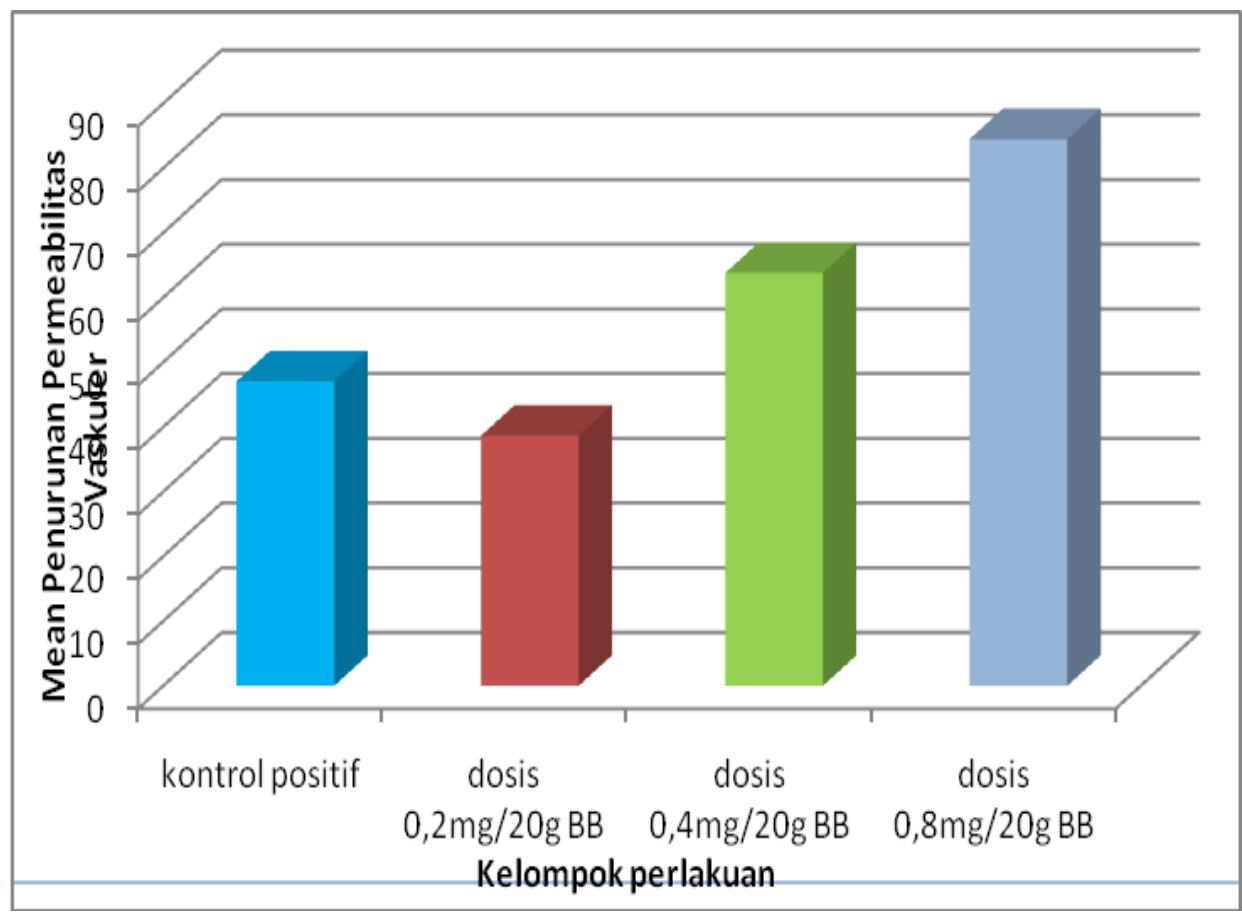

Selanjutnya untuk mengetahui hubungan vaskuler yang diperoleh dianalisis antara peningkatan dosis ekstrak etanol kulit menggunakan korelasi bivariat. Dari hasil buah apel dengan penurunan permeabilitas outputnya terlihat bahwa angka korelasi vaskuler, persentase penurunan permeabilitas peningkatan dosis dengan persentase penurunan 
permeabilitas vaskuler yang didapat 0,960 dengan probabilitas 0,000 . Hasil signifikansi ini juga dilihat dari adanya tanda (*) pada pasangan data yang dikorelasikan. (kolom Sig. (2-tailed)) pada lampiran12. Oleh karena angka korelasi $>0,5$ menunjukkan korelasi yang cukup kuat, sedangkan tanda + (positif) pada output menunjukkan adanya arah yang sama. Hal ini menunjukkan adanya hubungan yang cukup erat atau berkorelasi antara peningkatan dosis dengan persentase penurunan permeabilitas vaskuler yang menunjukkan bahwa semakin meningkatnya dosis maka akan terjadi peningkatan presentase penurunan permeabilitas vaskuler.Dapat disimpulkan bahwa antara peningkatan dosis dengan persentase penurunan permeabilitas vaskuler berkorelasi, $\mathrm{H}_{0}$ ditolak karena probabilitas $<0,01$

\section{Kesimpulan}

Ekstrak etanol kulit buah apel dengan dosis $\quad 0,2 \mathrm{mg} / 20 \mathrm{~g} \quad \mathrm{BB}, \quad 0,4 \mathrm{mg} / 20 \mathrm{~g} \quad \mathrm{BB}$ dan $0,8 \mathrm{mg} / 20 \mathrm{~g} \quad \mathrm{BB}$ memiliki kemampuan menurunkan permeabilitas vaskuler dengan rata-rata persentase berturut-turut sebesar $38,64 \%, 63,81 \%$ dan $84,49 \%$.

\section{Daftar Pustaka}

Achmad, H., 2001, Pengaruh Pemberian Ekstrak Psidium Guajava Terhadap Jumlah Trombosit pada Penderita Demam Berdarah Dengue di Bangsal Rawat Inap Penyakit Dalam RSUD Dr.
Syaiful Anwar Malang, Majalah kedokteran Universitas Brawijaya, Vol. 27, No.1, hal 1-5.

Anonim, 2008, Pyrus malus, L, available at http://www. warintek.ristek. go.id/pangan/kesehatan/tanaman_obat/de pkes/1-217.pdf (diakses 26 Maret 2008).

Anonim, 2008. Monograph Quersetin. $J$ alternative Medicine Review, Vol. 3, No. 2, Available at http://www.thorne.com/pdf/journal/32/quercetinmonograph.pdf (diakses 21 April 2008)

Asih, Y, 1998. Demam Berdarah Dengue Diagnosis, Pengobatan, Pencegahan, dan Pengendalian. Edisi 2, Penerbit Buku Kedokteran EGC, Jakarta

Backer, C.A., and Van Den Brink, R.C., 1965, Flora of Java, Noordhoff Groningen, The Netherland.

Begum, A. N,. and Terao, J,. 2002. Protective Effect of Quersetin Against Cigarrete Tar Extract-induced Impairment of Erythrocyte Deformability. $J$ Nutr Biocherm, Vol. 13, No 5, 265-72.

Baratawidjaja, K.G., 2004, Imunologi Dasar, Edisi 6, Balai Penerbit Fakultas Kedokteran Universitas Indonesia, Jakarta, 92

Budavari, S,. 1996. The Merck Index, Twelfth Edition, NJ: Merck \& CO., INC., 693.

Choi, E.J., Chee, K.M., and Lee, B.H., 2003, Anti- and Prooxidant Effect of Chronic Quercetin Administration in Rats. Eur J Pharmacol, Vol. 482, No. 1-3.

Harborne, 1987, Metode Fitokimia: Penuntun cara modern menganalisis tumbuhan,Diterjemahkan oleh Kosasih 
Padmawinata dan Iwang Soediro, Penerbit ITB, Bandung, 85-93.

Kusumawati, I., Sprapto, M., Rakhmawati., 2004, Uji Permeabilitas Vaskuler Ekstrak Daun Jambu Biji Sebagai Parameter Terapi Kebocoran Plasma Pada Infeksi Demam Berdarah Dengue, Laporan Penelitian, Jurusan Farmasi, Universitas Airlangga, Surabaya

Mochizuki, M., Kajiya, K., Tero, J., Kaji, K., Kumazawa, S., Nakayama, T., Shimoi, K., 2004, Effect of Quercetin Conjugates On Vascular Permeability and Expressions of Adhesion Molecules, Cambridge Journal, Vol 22, No 1/4, 201204

Nadesul, H., 2007, Cara Mudah Mengalahkan Demam Berdarah, Penerbit Buku Kompas, Jakarta

Yulianti, S., Irlansyah., J, Edi., dan W, Mufatis, 2007, Khasiat dan Mamfaat Apel, AgroMedia Pustaka, Jakarta, 8-30. 